\title{
Genetic Diversity and Gene Flow of Four South African Venturia inaequalis (Apple Scab) Populations
}

\author{
T. A. Koopman, J. C. Meitz-Hopkins, A. E. Bester-van der Merwe, K. R. Tobutt, C. Bester, and C. L. Lennox
}

First, fourth, and fifth authors: Agricultural Research Council Infruitec-Nietvoorbij (Institute of Deciduous Fruit), Private Bag X5026, Stellenbosch 7599, South Africa; first, second, and sixth authors: Fruit and Postharvest Pathology Research Programme, Department of Plant Pathology, Stellenbosch University, Private Bag X1, Matieland, Stellenbosch 7602, South Africa; and third author: Department of Genetics, Stellenbosch University, Private Bag X1, Matieland, Stellenbosch 7602, South Africa.

Accepted for publication 7 November 2016.

\begin{abstract}
Venturia inaequalis isolates were collected during the 2012/13 and 2013/14 seasons from the four principal apple growing regions of South Africa, Elgin $(n=114)$, Koue Bokkeveld $(n=126)$, Lower Langkloof $(n=92)$, and Upper Langkloof $(n=103)$. Sequence analysis of the ribosomal internal transcribed spacer (ITS) gene regions and genotyping with six (2012/13) and seven (2013/14) microsatellite (SSR) markers was conducted. A subset of 12 isolates from the individual ITS haplotype groups were sequenced for the translation elongation factor-1 alpha (TEF1) and the large subunit of the RNA polymerases II (RPB1) gene regions. Four haplotypes were found for ITS, whereas all isolates were identical for the TEF1 and RPB1 gene regions. The SSR markers revealed considerable variation with an average

clustered together with the Koue Bokkeveld population. The population from the warmer winter region, Elgin, clustered separately from the rest of the populations $\left(\Phi_{\mathrm{PT}}=0.076\right.$ to $\left.0.116 ; P \leq 0.05\right)$. Estimates of gene flow showed the highest migration rate from the Koue Bokkeveld, toward the Lower Langkloof $(\mathrm{M}=151.1)$, and the least migration to and from the Elgin region (average $\mathrm{M}=42.75$ ). Occasionally, identical genotypes (clones) were detected across seasons in the Koue Bokkeveld and Elgin area, which might contribute to overwintering conidia. From this study, it is evident that South Africa most likely has $V$. inaequalis subpopulations linked to diverse climatic conditions of the coastal Elgin region compared with the mountainous inland regions of the Koue Bokkeveld and the Langkloof.
\end{abstract} gene diversity $(\mathrm{H})$ of 0.675 . Multivariate analysis (discriminant analysis of principal components [DAPC]) revealed that the two Langkloof populations
Additional keywords: population genetic analysis.
Apple scab is caused by the heterothallic fungus Venturia inaequalis (Cooke) G. Wint. This ascomycete is one of the most important fungal diseases of apple (Malus pumila Mill.), in terms of economic crop losses. Its occurrence is common in South Africa and most other apple growing areas of the world (MacHardy 1996). The disease is particularly problematic in temperate regions with cool, moist weather in early spring. In semi-arid regions, such as parts of South Africa, Washington State, and most of Western Australia, it occurs only sporadically with scab lesions undetected most years. Disease incidence is high in most years in the Western Cape Province of South Africa, which has winter rainfall. The first incidence of apple scab in South Africa was reported in 1888 (MacOwan 1889). Control is mainly by use of fungicides with 8 to 16 fungicide sprays against the fungus each year in South Africa; however, significant crop losses still occur. High apple scab incidences have been reported in seasons with frequent rain events, causing dispersal of sexual inoculum and hindering fungicide application at the required time intervals. However, integrated management approaches such as planting resistant cultivars could potentially reduce scab inoculum pressure in orchards, as most commercial apple cultivars are susceptible to scab (Gessler et al. 2006; Holb 2007).

Members of the family Venturiaceae can infect various fruit tree genera: V. inaequalis and the saprophytic V. asperata Samuels and Sivan. infect apple (Malus pumila Mill.); V. carpophila Fisher infects peach (Prunus persica (L.) Batsch), V. cerasi Aderh. is found on cherry (Prunus avium L.), V. pyrina Aderh. on European pear (Pyrus communis Linn.), and V. nashicola Tanaka and Yamam infects Japanese pear (Pyrus pyrifolia Nakai). These Venturia

Corresponding author: T. A. Koopman; E-mail address: koopmant@arc.agric.za

(C) 2017 The American Phytopathological Society species can be differentiated into distinct clades on the basis of ribosomal internal transcribed spacer (ITS) sequence data (Beck et al. 2005; Bowen et al. 2011; Le Cam et al. 2001, 2002; Schnabel et al. 1999; Stehmann et al. 2001). Three haplotypes for $V$. inaequalis have been described on the basis of polymorphisms in highly conserved sequences often used for species identification of fungi (barcoding) (Beck et al. 2005; Schoch et al. 2009). These include the ITS region of ribosomal DNA genes (ITS1 and ITS2), the small and large subunits of the nuclear ribosomal RNA genes (SSU and LSU), and also three protein coding genes, namely translation elongation factor- 1 alpha (TEF1) and the largest and second largest subunits of the RNA polymerases II (RPB1, RPB2) (Beck et al. 2005; Schoch et al. 2009). Based on genetic and pathogenic data, two formae speciales belonging to $V$. inaequalis causing scab on loquat (Eryobotrya japonica [Thunb.] Lindley) and pyracantha (Pyracantha spp. Roem.) have previously been proposed (Le Cam et al. 2002). Substantial differentiation was however found among the three species on apple, loquat, and pyracantha with respect to the ITS region (Gladieux et al. 2010a; Le Cam et al. 2002).

Different molecular tools have been used to characterize genetic diversity of populations of $V$. inaequalis in various apple producing countries. Molecular markers such as random amplified polymorphic DNA (RAPDs) (Tenzer and Gessler 1999), restriction fragment length polymorphisms (RFLPs), amplified fragment length polymorphisms (AFLPs) (Xu et al. 2008), and simple sequence repeat markers (SSRs, also known as microsatellites) have been used to determine genetic diversity of $V$. inaequalis isolates from different regions of the world (Gladieux et al. 2008; Guérin et al. 2004; Tenzer and Gessler 1997; Xu et al. 2013). It was evident that there is more genetic diversity in European populations of the fungus than in populations from areas where apples have been introduced more recently (Gladieux et al. 2008; Tenzer and Gessler 1997, 1999). A more recent population genetic study, using 10 SSR 
markers, demonstrated high genotypic and genetic diversity and helped to resolve the evolutionary origin and distribution of the fungus (Gladieux et al. 2010b) suggesting that it originated in Central Asia, which is also the center of origin of Malus, as the host plant. There also appeared to be a greater genetic diversity among populations of $V$. inaequalis found on $M$. sieversii (considered to be the progenitor of the domestic apple) in Central Asia compared with European populations on M. pumila (Gladieux et al. 2008, 2010a). Two different apple growing regions exist in South Africa, with the Koue Bokkeveld (Ceres) area regarded as cold winter and Elgin and Langkloof areas as warm winter (Midgley and Lötze 2011). On the basis of pseudothecia formation at different temperatures and ascospore dispersal patterns, it has been suggested that the strains of $V$. inaequalis in Elgin and Koue Bokkeveld (Ceres) areas may differ from each other (Louw 1951; von Diest 2014). Such population adaptation to local climates might have implications on the effectiveness of management practices (von Diest et al. 2016).

Only one population genetic study has previously been conducted on South African $V$. inaequalis populations using 12 SSR markers and 12 isolates from the Grabouw (Elgin) area and concluded that this population was more similar to the European population than to populations from Brazil, Central Asia, Morocco, New Zealand, and North America (Gladieux et al. 2008).

For this study, $V$. inaequalis isolates were sampled from infected leaves and fruit from the four main apple growing regions of South Africa to determine the following: (i) if all scab-like symptoms are caused by $V$. inaequalis, (ii) if there are genetic differences between the populations from the different regions, and (iii) what the migration rates between the regions are.

\section{MATERIALS AND METHODS}

Fungal sampling and isolation. Apple scab isolates were collected during the spring or early summer months of the 2012/13 and 2013/14 growing seasons from fresh lesions on infected leaves and fruit, from 10- to 15-year-old orchards of various cultivars, in four apple growing regions. In the Eastern Cape region, 'Royal Gala' and 'Starking' were sampled from the Upper Langkloof; in the Western Cape province, 'Sundowner' and 'Cripps Pink' were sampled from the Lower Langkloof, 'Braeburn' and 'Golden Delicious' from the Elgin area, and 'Early Red' and 'Golden Delicious' from the Koue Bokkeveld (Fig. 1). Two separate lesions per tree with only one lesion per fruit or leave were sampled. These lesions are likely to have resulted from primary infections by ascospores, rather than from secondary infections from conidia, since only a small amount of asexual overwintering inoculum is found under South African conditions (von Diest 2014).

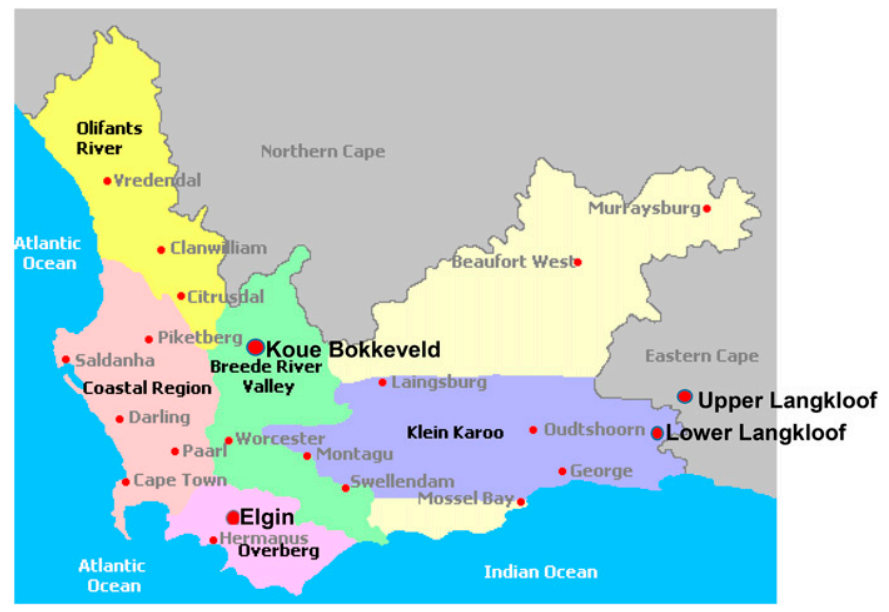

Fig. 1. Map of the four South African apple producing areas.
Single spore isolates were obtained from the fresh lesions of leaves and fruit using $2 \%$ water agar amended with streptomycin $(0.1 \mathrm{mg} /$ liter). Conidiospores from infected leaf samples were dispensed in autoclaved water and diluted by $1 / 10,1 / 100$, and 1/1,000 before they were poured onto $2 \%$ water agar plates and left to dry in a laminar flow cabinet. The plates were incubated at $18^{\circ} \mathrm{C}$ in a Labcon growth chamber for $24 \mathrm{~h}$ with $12 \mathrm{~h}$ day/night light period. After incubation, individual germinated spores were excised with a scalpel blade under a Leica stereomicroscope (WILD M8, Leica Microsystems, Germany) in a laminar flow cabinet and transferred to potato dextrose agar amended with streptomycin $\left(0.1 \mathrm{mg} / \mathrm{liter}\right.$; $\left.\mathrm{PDA}^{+}\right)$. These dishes were incubated at $18^{\circ} \mathrm{C}$ for more than a month; when the colony was large enough, samples were transferred to fresh $\mathrm{PDA}^{+}$medium and PDA slants.

DNA extraction. Approximately $60 \mathrm{mg}$ of mycelium of each single spored isolate was scraped from the surface of actively growing cultures on PDA and placed in an Eppendorf tube with $0.5 \mathrm{~g}$ of glass beads (2-mm-diameter) and subsequently snap frozen in liquid nitrogen. Mycelium was homogenized by shaking the tubes for $5 \mathrm{~min}$ at high frequency (30 shakes/s) using a Mixer Mill Type MM 301 (Retsch Gmbh \& Co. KG, Germany), equipped with a $2 \times$ 12 tube $(2 \mathrm{ml})$ adaptor set. Immediately after homogenization, DNA was extracted using the Wizard SV Genomic DNA purification system from Promega, according to the manufacturer's protocol (Promega). Genomic DNA was eluted with $35 \mu \mathrm{l}$ of sterile distilled water. The concentration of each DNA sample was then determined on a NanoDrop ND-1000 spectrophotometer (Thermo Fisher Scientific) and diluted to a final concentration of $100 \mathrm{ng} / \mu \mathrm{l}$.

ITS and coding gene amplification. First, a subset of 129 samples collected from the four regions was sequenced for the internal transcribed spacer region (ITS1-5.8S-ITS2) of the ribosomal DNA genes, using primers ITS1 and ITS4 (White et al. 1990). A smaller subset of 12 samples, representing all four identified ITS haplotypes, collected from Elgin, Koue Bokkeveld, and Langkloof regions, was then used for sequencing the two protein coding genes, translation elongation factor-1 alpha (TEF1) using primers EF1-983F and EF1-2218R, and a subunit of the RNA polymerase II (RPBI) using primers Rpb1-Ac and Rpb1-Cr (Matheny et al. 2002). This was done to identify which one of the previously described three haplotypes occurs in SA. The PCR amplification conditions for all gene regions were the same as described in Meitz-Hopkins et al. (2014) with the following annealing temperatures: ITS and TEF1, $60^{\circ} \mathrm{C} ; \mathrm{RPB} 1,55^{\circ} \mathrm{C}$. Sequencing reactions were conducted using the BigDye system (version 3.1 dye terminators, Applied Biosystems) after the PCR products had been purified using the MSBSpin PCRapace Clean-up System (Invitek GmbH, Berlin). The ABI 3130XL Genetic Analyzer available at the Central Analytical Facility, Stellenbosch University, was used for sequencing. Double strand consensus sequences were obtained through assembly in Geneious Pro 5.5 (Kearse et al. 2012, Biomatters Ltd., Auckland, New Zealand, available from http://www. geneious.com/). The sequences were then exported to MAFFT 5.85 (http://mafft.cbrc.jp/alignment/software/) for multiple sequence alignments (Katoh and Toh 2008). Alignments were manually adjusted in Sequence Alignment Editor (Rambaut 2002). Sequences representative of all genotypes found were submitted to GenBank (Accession numbers KX525662 to KX525667).

Microsatellite amplification and genotyping. Apple scab samples were genotyped using six published SSR markers: 1tc1a, 1tc1g, EmVi10, Vitc2/D, Vitg9/129, and Vitg11/70 (Celton et al. 2010; Guérin et al. 2004; Tenzer et al. 1999) (Table 1). Three other markers described by Celton et al. (2010), EmVi1, EmVi2, and EmVi3, were also tested, but data were discarded because of null alleles. Another three SSR markers (2014), Vitc1/2, Vica9/x, and Vitc1/82, as described in Guérin et al. (2004) were tested. Of these, Vitc1/2 was used to genotype the 2013/14 V. inaequalis samples, since the other two markers, Vica9/x and Vitc1/82, were not polymorphic in the South African population. For the first batch of markers, PCR amplification was done in two multiplex reactions 
with reaction volumes of $25 \mu$ l containing $2 \mu$ of DNA solution, 1× KAPA buffer (Kapa Biosystems (Pty) Ltd., Cape Town, South Africa), $0.08 \mathrm{mM}$ dNTPs (Bio-39025, Bioline, UK), $0.625 \mathrm{U}$ of KAPA hotstart Taq polymerase (Kapa Biosystems, DKAPKK5513), and $1.5 \mathrm{mM} \mathrm{MgCl} 2$. The concentrations for the SSR primers for multiplex reaction 1 were as follows: Vitc2/D, $0.16 \mu \mathrm{M}$; EmVi10, $0.032 \mu \mathrm{M}$; and $1 \mathrm{tc} 1 \mathrm{~g}, 0.04 \mu \mathrm{M}$; and for multiplex reaction 2: 1tc1a, $0.08 \mu \mathrm{M}$; Vitg9/129, $0.04 \mu \mathrm{M}$; and Vitg11/70, $0.04 \mu \mathrm{M}$. Forward primers were labeled with fluorescent dyes as follows: EmVi10, Vitg9/129, and Vitc2/D with 6-FAM, Vitg11/70 with VIC and 1tc1a and 1tc1g with NED (Applied Biosystems, UK). PCR was performed in a Gene Amp PCR system 9700 (Applied Biosystems, Foster City, CA) using the following cycling conditions: $40 \mathrm{~s}$ at $94^{\circ} \mathrm{C}, 20$ cycles $55-45$ (touch down, $-0.5^{\circ} \mathrm{C}$ per cycle) followed by PCR of 30 cycles at $96^{\circ} \mathrm{C}, 40 \mathrm{~s}$ at $45^{\circ} \mathrm{C}$, and $20 \mathrm{~s}$ at $72^{\circ} \mathrm{C}$ with a final extension of $10 \mathrm{~min}$ at $72^{\circ} \mathrm{C}$. Successful PCR amplification was verified by agarose gel electrophoresis and ethidium bromide staining. Gels were viewed using the GELDOC system (Bio-Rad, Hercules, CA). After visualization, $\mathrm{PCR}$ products were diluted with water in 1:100 or 2:100 depending on the amplification success.

A single PCR amplification reaction was done for marker Vitc1/2, and the PCR product was mixed in water $(1 / 100$ or $2 / 100)$ before fragment sizing. The forward primers were labeled with an M13 tail and $0.05 \mathrm{mM}$ dye (HEX for Vitc1/2, NED for Vica9/x and Vitc1/82) was added to the reaction as described in Schuelke (2000). Primer concentrations were $0.01 \mu \mathrm{M}$ for the forward primers and $0.05 \mu \mathrm{M}$ for the reverse primers, and the same PCR conditions were used as for the multiplex reactions.

For both batches of primers, following PCR, $1 \mu \mathrm{l}$ of the diluted product was mixed with a Liz 500 internal size standard/formamide mix (1/14) (Applied Biosystem). Sizing was performed on an ABI 3100 genetic analyzer (Applied Biosystems) and using Gene Mapper 3.0 (ABI PRISM). Positive control samples were added between seasons for calibration of allele sizes. Samples showing identical allele patterns across all loci were interpreted as clonal progeny. Alleles that appeared to have $1 \mathrm{bp}$ differences in product sizes at one locus were amplified in singleplex reactions and sequenced to check for distinctness.

Population genetic analyses. All microsatellite data were analyzed using clone-corrected data sets to prevent over-representation of alleles in frequently occurring clones. Basic genetic diversity estimates within the different $V$. inaequalis populations, such as the numbers of alleles, private alleles, and most frequently occurring alleles, were calculated using the population genetic software GenALEX 6.5b3 (Peakall and Smouse 2006). The evenness of distribution of genotypes within a population was measured by normalizing $H^{\prime}$ for variable sample size by scaling the index by $H^{\prime}{ }_{\text {max }}$, which is the maximum genotypic diversity for a given sample size expressed here as the logarithm of the sample size $\ln (n)$ (Nei 1973). Population differentiation $\left(\Phi_{\mathrm{PT}}\right)$ between pairwise comparisons of all populations was analyzed to determine which populations were genetically differentiated from each other (Weir 1997). The analysis of the molecular variance (AMOVA) was determined in order to determine the variance in allele frequencies within and among the populations, in GenALEX 6.5b3. A Mantel test for isolation-by-distance was also performed using 99 permutations in GenALEX 6.5b3. The interrelationships between the apple scab fungal populations from the different regions were also visually explored by discriminant analysis of principal components (DAPC) using ADEGENET (Jombart 2008) for R software and a principal component analysis (PCA) using GenALEX 6.5b3.

STRUCTURE 2.2 was used to detect the most likely number of populations $(K)$ among the $V$. inaequalis isolates based on allele frequencies per locus using a Bayesian approach (Pritchard et al. 2000). Ten independent runs of $K=1$ to $K=4$ (corresponding to the four regions sampled from) were performed with 1,000,000 Markov chain Monte Carlo (MCMC) iterations following a burn-in period of 100,000 iterations. For these analyses, the admixture ancestry model and a value of one for the parameter, Lambda, of distribution of allelic frequencies, were used (Pritchard et al. 2000). The LnP(D) (posterior probability of the data for a given $K$ ) values calculated by STRUCTURE over the $K$-values tested were used to calculate delta $\mathrm{K}(\Delta K)$ according to Evanno et al. (2005). An ad hoc quantity $(\Delta K)$ was calculated on the basis of the second order rate of change of the likelihood $(\Delta K)$ using $\Delta K=\mathrm{m}([\mathrm{L}$ ' $\mathrm{K}]) / \mathrm{s}[\mathrm{L}(\mathrm{K})]$. The highest value of $\Delta K$ presented the most likely value of $K$. Finally, the program MIGRATE was used for the calculation of the maximum likelihood estimation of migration rates between the four populations (Beerli and Felsenstein 1999).

\section{RESULTS}

V. inaequalis species confirmation. Out of the 129 isolates from the four South African apple growing regions that were genotyped using the ITS1 and ITS4 primers, four possible haplotypes were found for the ITS gene region with one to three nucleotide changes with respect to the seven CBS reference isolate sequences (Fig. 2). The South African sequences and the reference ITS sequences clustered together and were separated from the other Venturia species. Most of the samples fall into ITS haplotype group I (KX52662) and IV (KX52665) with 53.07 and $42.30 \%$, respectively. Only 0.15 and $0.31 \%$ of the samples were in haplotype groups II (KX52663) and III (KX52664).

Sequences for the RPB1 and TEF1 gene regions indicated all South African isolates were identical to the GenBank reference sequence and no nucleotide changes were found in these gene regions (data not shown).

TABLE 1. Summary of average gene diversity, over 2 years, of seven simple sequence repeat markers used to determine the differences in the South African Venturia inaequalis populations from four growing regions

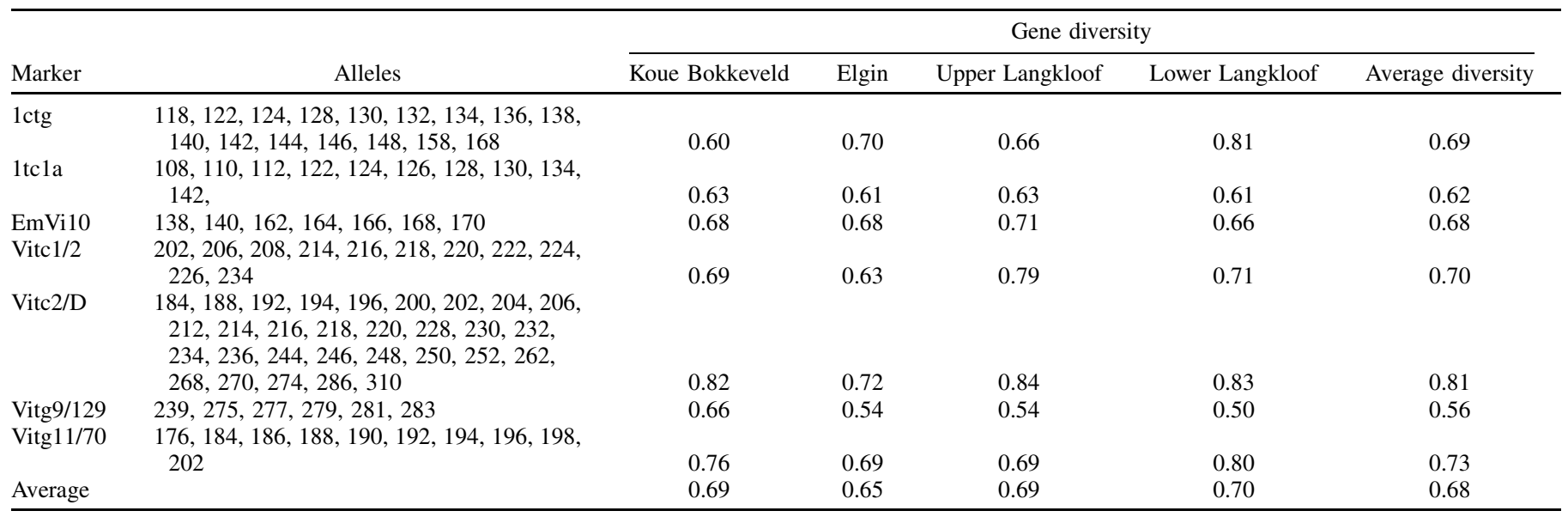


Microsatellite marker characteristics. To determine the variation of the South African populations in the different apple growing regions, a total of 169 (2012/13) and 266 (2013/14) single spore apple scab isolates were genotyped using six and seven polymorphic SSR markers respectively. One peak per isolate, consistent with the haploid nature of the fungus, was present for all the loci. Markers Vica9/x and Vitc1/82 were tested in 2013/14 but were monomorphic with the only peaks at $246 \mathrm{bp}$ (Vica9/x) and $185 \mathrm{bp}$ (Vitc1/82).

The remaining SSR markers used in the study were highly polymorphic as shown by the allele frequencies and average gene diversity that ranged from 0.56 to 0.81 (average of 0.675 ) (Table 1). The most variable marker was Vitc2/D with 30 alleles and average gene diversity of 0.81 , whereas Vitg9/129 had only six alleles and a gene diversity of 0.56 (Tables 1 and 2). The average gene diversity over all the SSR markers was the highest in the Lower Langkloof $(0.70)$ and the lowest in the Elgin population (0.65; Table 1). Base pair differences between certain alleles were found for three of the markers used, Vitg9/129 (275, 276, 277, 279, 280, 282, and 283 bp),
Vitg11/70 (191, 192, 193, 194, and 195 bp), and 1tc1a (107 and $108 \mathrm{bp}$ ). When these product samples were sequenced, it was found that for marker 1tcla, there were no differences between the two alleles. However, all single base pair differences for markers Vitg9/ 129 and Vitg11/70 were real and corresponded to single base pair differences within the flanking regions of the SSR repeat. Marker Vitc2/D was difficult to score, especially the alleles with PCR products larger than $268 \mathrm{bp}$, and PCR amplification within a single reaction had to be repeated for most samples.

Identical genotypes for the six markers were found for two isolates in the Koue Bokkeveld and four isolates each in the two Langkloof area within a season while two identical isolates each were found between seasons within the same orchard for these two regions.

Population genetic structure analysis by region. Private alleles, or alleles unique to a population, were identified for all the populations with the majority in the Elgin region (Table 2). Population differentiation $\left(\Phi_{\mathrm{PT}}\right)$ values ranged from 0.030 to $0.116(P \leq 0.05)$

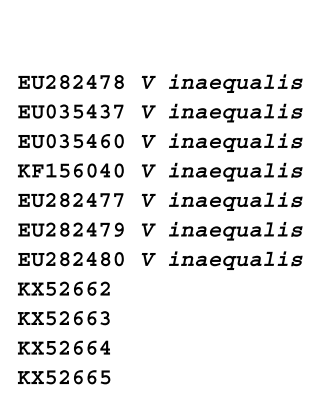

EU282478 $V$ inaequalis EU035437 $V$ inaequalis EU035460 $\mathrm{V}$ inaequalis KF156040 $\mathrm{V}$ inaequalis EU282477 $V$ inaequalis EU282479 $V$ inaequalis EU282480 $\mathrm{V}$ inaequalis KX52662

$\mathrm{KX} 52663$ $\mathrm{KX} 52664$ KX52665

\begin{tabular}{|c|c|c|c|c|c|c|}
\hline & & 410 & 420 & 430 & 440 & \\
\hline & & $\ldots|\ldots|$ & $\ldots|\ldots|$ & $\ldots|\ldots|$ & $\ldots|\ldots|$ & . \\
\hline EU2 82478 & $V$ inaequalis & AАTTTTCCAG & GCAGGGTTGG & CTAATTCCGG & CAGGC--GGG & $\mathrm{GC}$ \\
\hline EU035437 & $V$ inaequalis & $\cdots \ldots \ldots \ldots$ & $\cdots \cdots$ & $\ldots \ldots \ldots$ & $\ldots \ldots--\ldots$ & . \\
\hline EU035460 & $V$ inaequalis & $\ldots \ldots \ldots$ & $\cdots \cdots$ & $\cdots \cdots$ & $\ldots \ldots-\ldots$ & . \\
\hline KF156040 & $V$ inaequalis & $\ldots \ldots \ldots$ & $\ldots \ldots \ldots$ & $\ldots \ldots \ldots$ & $\ldots \ldots-\ldots$ & $\ldots$ \\
\hline EU282477 & $V$ inaequalis & $\cdots$ & & $\ldots$ & $\ldots \ldots-\ldots$ & . \\
\hline EU282479 & $V$ inaequalis & $\cdots \cdots \cdots$ & $\cdots$ & $\cdots \cdots$ & $\ldots \ldots-\ldots$ & . \\
\hline EU282480 & $V$ inaequalis & $\ldots \ldots \ldots$ & $\ldots \ldots \ldots$ & $\ldots \ldots$ & $\ldots \ldots-\ldots$ & . . \\
\hline $\mathrm{KX} 52662$ & & $\ldots \ldots$ & $\ldots \ldots \ldots$ & $\ldots \ldots \ldots$ & $\ldots \ldots-\ldots$ & . \\
\hline KX52663 & & $\ldots$ & & $\ldots$ & $\ldots \ldots--$ & \\
\hline $\mathrm{KX52664}$ & & $\ldots \ldots$ & $\cdots$ & $\cdots$ & $\ldots$ & . \\
\hline $\mathrm{KX52665}$ & & $\ldots \ldots$ & $\ldots \ldots$ & $\ldots$ & $\ldots \ldots--\ldots$ & \\
\hline & & 510 & 520 & 530 & 540 & \\
\hline & & $\ldots|\ldots|$ & $\ldots|\ldots|$ & $\ldots \ldots|\ldots|$ & $\ldots \ldots|\ldots|$ & . \\
\hline EU282478 & $V$ inaequalis & AGGGTGGGGA & -TGCGCCCGA & AGGC- - T-AA & СССАТТААТ $I$ & AT \\
\hline EU035437 & $V$ inaequalis & $\cdots \cdots$ & $-\ldots \ldots \ldots$ & $\ldots--\ldots$ & $\ldots \ldots \ldots$ & . \\
\hline EU035460 & $V$ inaequalis & $\ldots \ldots \ldots$ & $-\ldots \ldots \ldots$ & $\ldots--.-\ldots$ & $\ldots \ldots \ldots$ & . \\
\hline KF156040 & $V$ inaequalis & $\ldots \ldots \ldots$ & $-\ldots \ldots$ & $\ldots .-\ldots$ & $\ldots \ldots \ldots$ & $\cdots$ \\
\hline EU2 82477 & $V$ inaequalis & $\ldots \ldots \ldots$ & $-\ldots \ldots$ & $\ldots \mathrm{T}----\ldots$ & $\ldots \ldots \ldots \mathrm{A}$ & $\mathrm{T}$. \\
\hline EU2 82479 & $V$ inaequalis & $\ldots \ldots$ & -. & $\ldots \mathbf{T}---\ldots$ & $\ldots \ldots-\ldots \mathrm{A}$ & T. \\
\hline EU2 82480 & $V$ inaequalis & $\cdots \cdots$ & $-\ldots$ & $\ldots \mathbf{T}----\ldots$ & $\ldots \ldots-\ldots \mathrm{A}$ & . \\
\hline $\mathrm{KX} 52662$ & & $\ldots \ldots \ldots$ & $-\ldots$ & $\ldots--.$. & $\ldots \ldots \ldots$ & .. \\
\hline $\mathrm{K} \times 52663$ & & $\ldots \ldots \ldots$ & $-\ldots \ldots$ & $\ldots--.$. & $\ldots \ldots \ldots$ & $\cdots$ \\
\hline $\mathrm{KX52664}$ & & $\ldots \ldots$ & - . & $\ldots--.$. & $\ldots \ldots$ & \\
\hline $\mathrm{KX} 52665$ & & & _- & & & \\
\hline
\end{tabular}

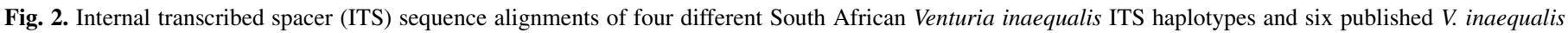
ITS sequences, showing differences from EU282478 V. inaequalis reference sequence (Crous et al. 2007; Samerpitak et al. 2014; Sanchez-Torres et al. 2009).

\begin{tabular}{|c|c|c|c|c|c|c|c|c|}
\hline & 0 & 0 & 40 & 50 & $6 c$ & 70 & 80 & 9 \\
\hline$\ldots|\ldots|$ & $\ldots|\ldots|$ & $\ldots|\ldots|$ & $\ldots|\ldots|$ & $\ldots|\ldots|$ & $\ldots|\ldots|$ & $\ldots|\ldots|$ & $\ldots|\ldots|$ & $\ldots|\ldots|$ \\
\hline TGCTTAAGT & TCAGCGGGTA & TCCCCACCTG & ATCCGAGGCC & AACCTTGT-A & AATAT-AGGT & TTC-GGGGCG & GCCGGCCGAC & AGACACTCCG \\
\hline & $\cdots$ & & & $\cdots$ & $\ldots \ldots$-G. & $\ldots-\ldots \ldots$ & $\ldots \mathbf{T} \ldots \ldots$ & . \\
\hline & $\cdots \cdots$ & $\ldots \ldots \ldots$ & $\cdots \cdots$ & $\cdots-$ & $\ldots$ - G. & $\ldots-\ldots \ldots$ & $\ldots \mathbf{T}$. & $\cdots \cdots$ \\
\hline & $\ldots \ldots \ldots$ & $\ldots$ & $\ldots \ldots$ & $\ldots$ & $\ldots \ldots-\mathbf{G} \ldots$ & $\ldots-\ldots \ldots$ & $\ldots$ т. $\ldots \ldots$ & $\ldots \ldots$ \\
\hline & $\ldots \ldots \ldots$ & $\ldots \ldots \ldots$ & $\ldots \ldots \ldots$ & $\ldots$ & $\ldots \ldots-\ldots$ & $\ldots-$ & $\ldots \ldots$ & $\cdots \cdots$ \\
\hline & $\ldots \ldots \ldots$ & $\cdots \cdots$ & $\ldots \ldots \ldots$ & $\cdots$ & $\ldots \ldots-\ldots$ & $\ldots-\ldots \ldots$ & $\ldots \ldots \ldots$ & $\ldots \ldots$ \\
\hline & $\ldots$ & $\ldots$ & $\ldots$ & $\ldots$ & $\ldots$-G. & $\ldots-$ & $\ldots \mathbf{T} \ldots \ldots$ & $\ldots \ldots$ \\
\hline & $\cdots$ & $\cdots$ & & & $\ldots \ldots-\ldots$ & $\ldots-$ & $\ldots \ldots \ldots$ & $\cdots \cdots$ \\
\hline & & & & $\cdots$ & $\ldots \ldots-\mathbf{G}$ & $\ldots-$ & $\ldots$ T. . G & \\
\hline & $\ldots$ & $\cdots$ & $\cdots$ & $\ldots$ & $\ldots .-\mathrm{G}$. & $\ldots-$ & $\ldots \mathbf{T} \ldots \ldots$ & $\cdots$ \\
\hline & & & & & $\ldots \ldots-\mathbf{G} \ldots$ & & & \\
\hline
\end{tabular}

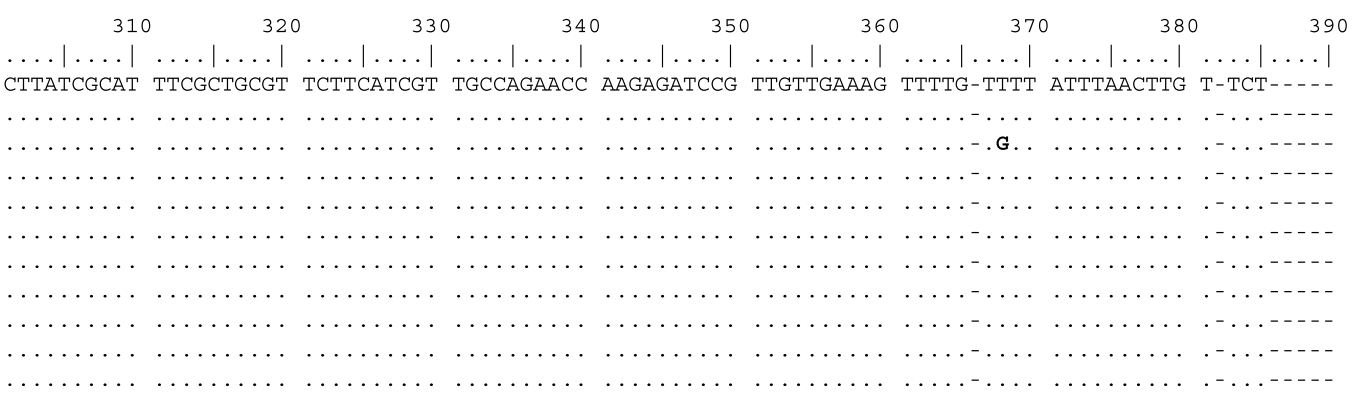


(Table 3). This indicated that between 3.0 and $11.6 \%$ of the variation was found among the populations and between 88.4 and $97.0 \%$ of the variation was found within populations. Populations from the two Langkloof areas were the least differentiated $\left(\Phi_{\mathrm{PT}}=0.030 ; P \leq 0.05\right)$, while the highest differentiation was found between the Elgin and the Lower Langkloof populations $\left(\Phi_{\mathrm{PT}}=0.116 ; P \leq 0.05\right)$. Interestingly, the Koue Bokkeveld multilocus genotypes were more similar $\left(\Phi_{\mathrm{PT}}=\right.$ $0.036)$ to the Lower Langkloof than the Elgin population $\left(\Phi_{\mathrm{PT}}=0.076\right)$, although the population from Koue Bokkeveld was collected from a location more than $600 \mathrm{~km}$ apart from the Lower Langkloof region and only about $150 \mathrm{~km}$ from the Elgin area. $\Phi_{\mathrm{PT}}$ values for isolates within the same area, from the two different orchards where isolates were collected, indicate less than $0.1 \%$ variation among the populations. There was no correlation between the differentiation and geographical distance among the different regions $\left(R^{2}=0.261 ; P=0.040\right)$.

Nei's unbiased genetic diversity measurements showed the smallest/ lowest genetic distance $(0.131)$ between the two Langkloof populations, the closest to zero, and the highest genetic distance (0.376) was found between the Upper Langkloof and Elgin populations. A high molecular variance for the South African populations was found, where most of the variance was within the populations (94\%) and only $6 \%$ among the populations (Table 4). The high level of genetic diversity is possibly due to the populations being almost exclusively sexually outcrossing, as also indicated by the association index $\left(\mathrm{I}_{\mathrm{A}}=(\mathrm{Vo} / \mathrm{Ve})-\right.$ $1=0.0058, P=0.03)$.

The DAPC analysis displayed the interrelationship of the four South African $V$. inaequalis haplotypes. The two Langkloof populations clustered together and overlapped with the Koue Bokkeveld population. The Elgin population was clustered separately (Fig. 3). A twodimensional display of allele distribution in the four $V$. inaequalis populations was obtained with principal component analysis (PCA). The axes (principal axis 1 and principal axis 2) explained 23.24 and $12.66 \%$ of the variance, respectively.

According to STRUCTURE and $\Delta K$, the true number of clusters was estimated to be two (Figs. 2 and 4), indicating that the V. inaequalis population in this study can be divided into two ancestral clusters.

MIGRATE indicated significant gene flow of $V$. inaequalis isolates between the different regions, which suggested migration between regions. The highest migration rate happened toward the Lower Langkloof area and the lowest rate from that area toward all other areas, with the highest migration rate from the Koue Bokkeveld toward the other regions. The warmer winter region, Elgin, was shown to be more isolated with a lower migration rate toward this region (Fig. 5).

Population genetic structure analysis by cultivar. Very little to no population differentiation, $\Phi_{\mathrm{PT}}$ values ranging from 0.000 to 0.015 , were found between isolates from different cultivars within the same region for both years, indicating less than $1.5 \%$ variation between the orchards per region. The total number of alleles and the number of private alleles between orchards in the same region were the same with maximum two to three allele differences in total number of alleles. The exception was in 2013/14 with 11 more alleles (five private alleles) in 'Braeburn' than in 'Golden Delicious' orchards from the Elgin region.

\section{DISCUSSION}

All the South African samples that derived from lesions on fruit and leaves and sequenced for the ITS gene region were positively identified as $V$. inaequalis. Nucleotide variation was found within the ITS gene region with four possible haplotypes for the South African population that also differed from the published reference sequences. Nucleotide variation in the ITS1-5.8S-ITS2 region of $V$. inaequalis, based on single base substitutions or single base insertions/deletions, was found in previous studies (Beck et al. 2005; Schnabel et al. 1999). Different intron alleles were identified on the basis of restriction fragment patterns of DNA amplified with primers ITS1-F and ITS2. It was suggested that the polymorphism in the ITS gene region might be due to recombination within the locus and it could be that the different alleles evolved independently in the different populations (Schnabel et al. 1999; Tenzer and Gessler 1997). The South African sequences and $V$. inaequalis reference sequences differed from those of the other

TABLE 3. Pairwise Fst values $\left(\Phi_{\mathrm{PT}}\right)$ calculated over all simple sequence repeat loci in Venturia inaequalis isolates collected from four apple growing regions in South Africa

\begin{tabular}{lcccc}
\hline Populations & $\begin{array}{c}\text { Koue } \\
\text { Bokkeveld }\end{array}$ & $\begin{array}{c}\text { Upper } \\
\text { Langkloof }\end{array}$ & Elgin & $\begin{array}{c}\text { Lower } \\
\text { Langkloof }\end{array}$ \\
\hline Koue Bokkeveld & - & 0.001 & 0.001 & 0.001 \\
Upper Langkloof & 0.060 & - & 0.001 & 0.001 \\
Elgin & 0.076 & 0.116 & - & 0.001 \\
Lower Langkloof & 0.039 & 0.030 & 0.089 & - \\
\hline
\end{tabular}

TABLE 4. Distribution of genetic variation within and among four Venturia inaequalis populations, as determined with the analysis of molecular variance ${ }^{\mathrm{a}}$

\begin{tabular}{lrrrcc}
\hline Source & df & \multicolumn{1}{c}{ SS } & \multicolumn{1}{c}{ MS } & $\begin{array}{c}\text { Estimated } \\
\text { variance }\end{array}$ & \% Variance \\
\hline Among populations & 3 & 44.312 & 14.771 & 0.187 & $7 \%$ \\
Within populations & 262 & 644.041 & 2.458 & 2.458 & $93 \%$ \\
Total & 265 & 688.353 & & 2.645 & $100 \%$ \\
\hline
\end{tabular}

a Number of migrants $=7.629, P=0.010 ; \mathrm{df}$, degrees of freedom; SS, sum of squares; and MS, mean sum of squares.

TABLE 2. Summary for the six SSR markers genotyped in four populations of the South African Venturia inaequalis isolates [total number genotyped per season in square brackets]: number of alleles $(N)$ with number of private alleles in brackets, allele size range and the most common allele size (mode) together with its frequency of occurrence in brackets

\begin{tabular}{|c|c|c|c|c|c|c|c|c|c|c|c|c|}
\hline & \multicolumn{3}{|c|}{ Koue Bokkeveld $[46,80]$} & \multicolumn{3}{|c|}{ Elgin $[42,72]$} & \multicolumn{3}{|c|}{ Upper Langkloof $[42,61]$} & \multicolumn{3}{|c|}{ Lower Langkloof $[39,53]$} \\
\hline & $N$ & Size range & Mode $^{b}$ & $N$ & Size range & Mode & $N$ & Size range & Mode & $N$ & Size range & Mode \\
\hline \multicolumn{13}{|l|}{$2012 / 13$} \\
\hline EmVi10 & $5(0)$ & $140-168$ & $140(46)$ & $4(1)$ & $164-266$ & 168 (54) & $6(1)$ & $138-168$ & $166(40)$ & $4(0)$ & $140-168$ & $140(59)$ \\
\hline Vitc2/D & $9(1)$ & $190-246$ & $214(36)$ & $11(4)$ & $194-268$ & $214(41)$ & $11(2)$ & $192-246$ & 214 (39) & $9(0)$ & $194-268$ & $194(29)$ \\
\hline Vitg $9 / 129$ & $4(0)$ & $275-283$ & $275(53)$ & $6(2)$ & $188-283$ & 275 (53) & $3(1)$ & $275-279$ & 275 (73) & $5(1)$ & 239-283 & $275(61)$ \\
\hline $1 \mathrm{ctg}$ & $11(2)$ & $122-148$ & $136(61)$ & $9(1)$ & $122-146$ & $136(49)$ & $9(1)$ & $128-168$ & $136(53)$ & $11(0)$ & $122-158$ & $136(36)$ \\
\hline $1 \mathrm{tc} 1 \mathrm{a}$ & $6(0)$ & $108-130$ & $108(55)$ & $5(1)$ & $108-130$ & 128 (49) & $4(0)$ & $108-128$ & $108(51)$ & $5(0)$ & $108-130$ & $108(55)$ \\
\hline EmVi10 & $4(0)$ & $140-168$ & $140(38)$ & $4(0)$ & $140-168$ & $168(40)$ & $6(1)$ & $138-168$ & $166(40)$ & $6(1)$ & $138-170$ & $140(47)$ \\
\hline Vitc1/2 & $8(1)$ & $202-234$ & 218 (49) & $7(0)$ & 204-224 & $206(54)$ & $10(0)$ & $202-226$ & 224 (34) & $7(0)$ & $204-224$ & $224(37)$ \\
\hline Vitc2/D & $16(3)$ & $184-248$ & $214(31)$ & $17(6)$ & $188-274$ & $214(50)$ & $13(2)$ & $192-286$ & 214 (29) & 11 (1) & $192-310$ & $194(25)$ \\
\hline Vitg $9 / 129$ & $5(1)$ & $275-283$ & 275 (47) & $4(0)$ & $184-283$ & 275 (64) & $4(0)$ & $275-283$ & 275 (59) & $4(0)$ & $275-283$ & $275(67)$ \\
\hline Vitg11/70 & $9(1)$ & $176-202$ & $192(33)$ & $8(1)$ & $184-282$ & 192 (49) & $6(0)$ & $186-196$ & 190 (49) & $9(1)$ & 184-198 & $194(30)$ \\
\hline
\end{tabular}


Venturia species as previously reported in other studies (Beck et al. 2005; Bowen et al. 2011; Le Cam et al. 2001, 2002; Schnabel et al. 1999; Stehmann et al. 2001). No differences in TEF1 and RPB1 gene regions were found for the South African samples. These gene regions are conserved and few nucleotide changes were expected.

The SSR markers used in this study were highly variable (7 to 29 alleles per locus; gene diversity: 0.560 to 0.810 ), and results generally correspond with those of previous population genetic studies by Guérin et al. (2004) and Xu et al. (2013) in Europe. However, markers Vica9/x and Vitc1/82 showed only one allele in the current study as opposed to 8 to 10 alleles reported previously. The overall genetic variation among the individual $V$. inaequalis isolates was $97 \%$ in the different apple growing regions. The South African apple scab population can thus be considered as a sexually outcrossing

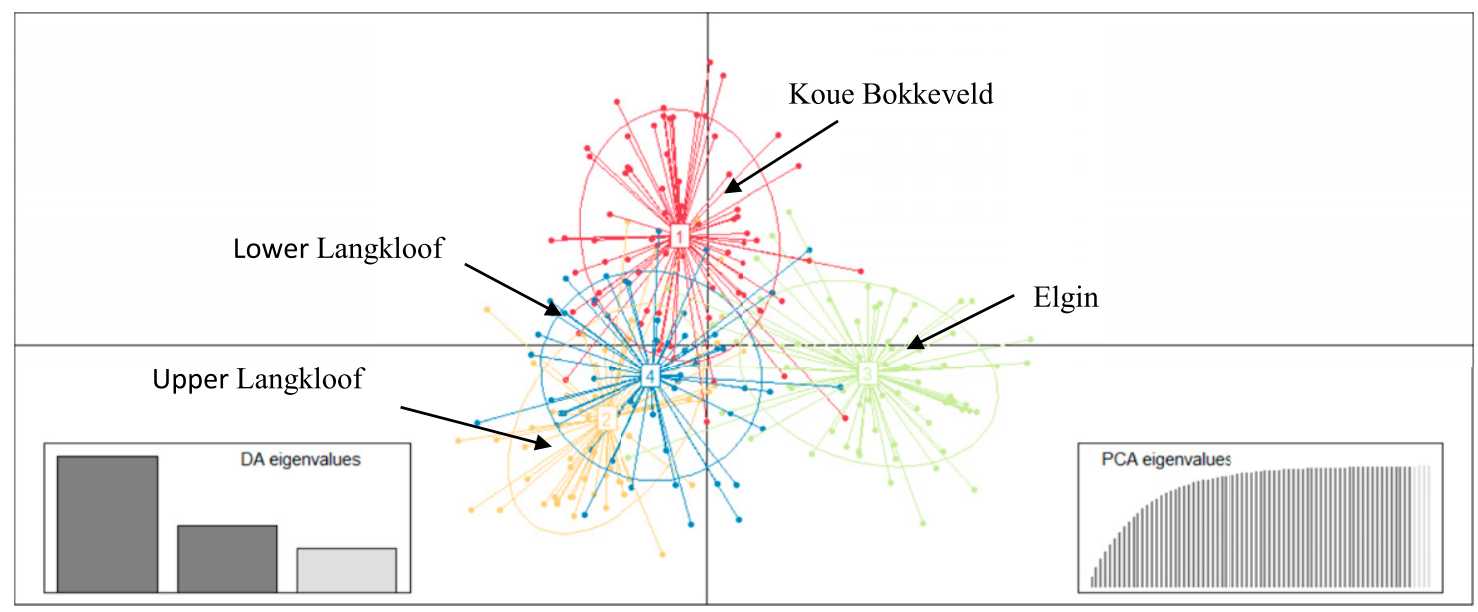

Fig. 3. Discriminant analysis of principal components (DAPC) to determine the interrelationship of four South African populations using ADEGENET for $\mathrm{R}$ software. Colored ellipses correspond to geographical populations. The eigenvalue graphs indicate the number of discriminant functions (DA) and principal component analysis (PCA) axes retained for the computations.

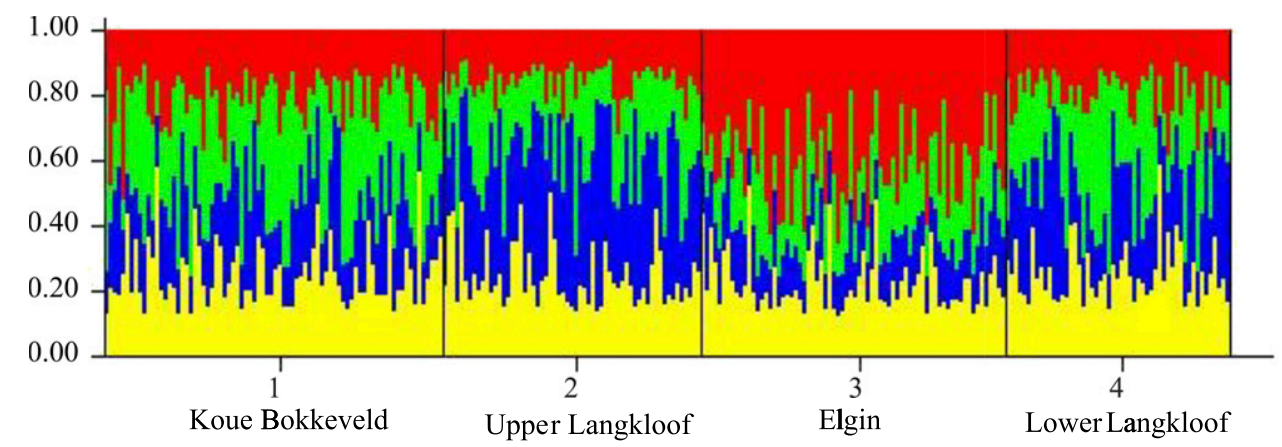

Fig. 4. STRUCTURE assignment plots of Venturia inaequalis from four apple producing areas in South Africa with $K=4$ (number of populations) performed in the program STRUCTURE. The shades of gray correspond to the four ancestral clusters (K) tested for (representing the likelihood of membership of each cluster).

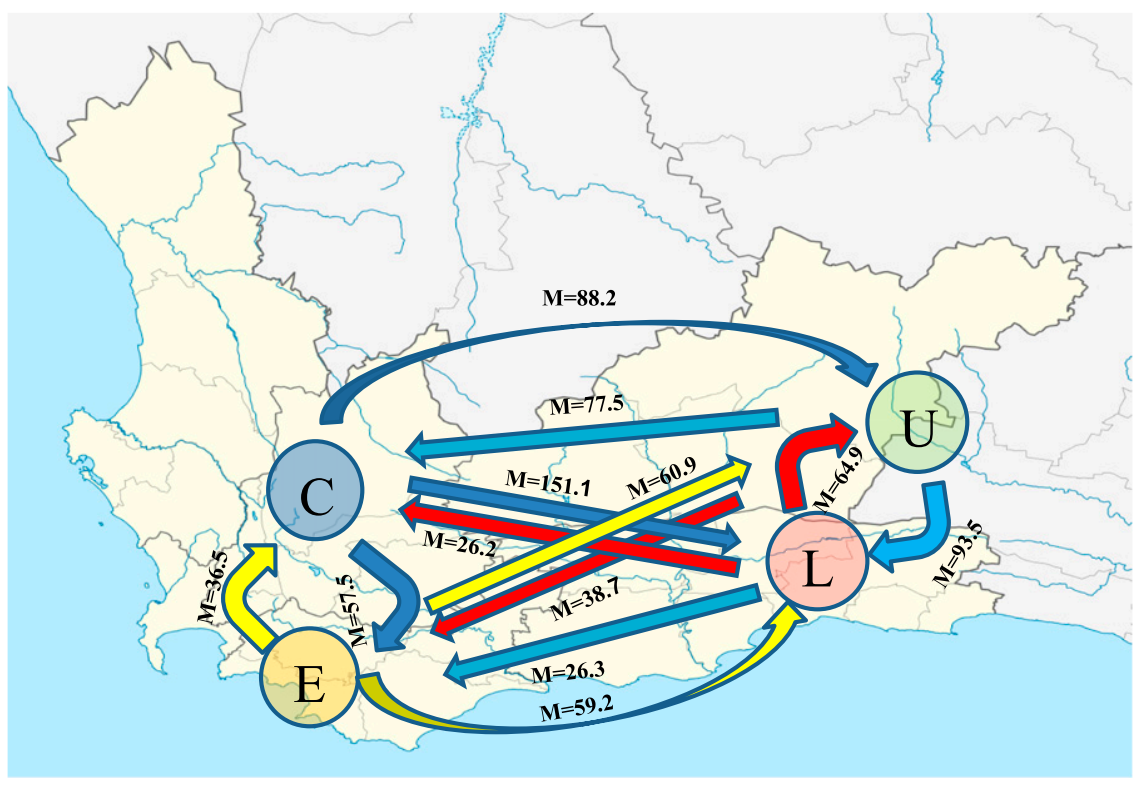

Fig. 5. The gene flow pattern of Venturia inaequalis from the four apple growing regions in South Africa. C = Koue Bokkveld, E = Elgin, U = Upper Langkloof, $\mathrm{L}=$ Lower Langkloof, and $\mathrm{M}=$ the migration rate of $\mathrm{V}$. inaequalis samples per season. 
population $\left(\mathrm{I}_{\mathrm{A}}=0.0058, P=0.03\right)$, as most of the samples that were collected and genotyped showed individual genotypes for the SSR loci. This is due to sampling of lesions early in the apple growing season, primary infections from ascospores, and also to sampling from leaves and fruit that were separated, with only two or three leaves per tree. It is thus unlikely that these samples resulted from secondary infection. Clones were found within the season (Koue Bokkeveld and Upper and Lower Langkloof) and between the seasons (Koue Bokkeveld and Elgin), but there were at most two such isolates/clones per region. Overwintering of viable secondary inoculum on pygmy fruit and in apple buds early in the apple growing season was reported in a previous study in South Africa and may have contributed to the occurrence of clones from one season to the next (von Diest 2014). The genetic distance of the coastal Elgin region compared with the mountainous Upper Langkloof region was 0.376. This is similar to results from a study of the lower coastal plains in Israel using three SSR markers (Böhm et al. 2003. The maximum genetic distance reported by Böhm et al. (2003) between isolates from the Golan Heights and the lower coastal Be'er Tuvia region was 0.484. These isolates were separated by a geographic distance of about $200 \mathrm{~km}$. Other isolates from more closely located regions, but different heights above sea level also indicated differences between populations with a genetic distance of 0.393 . The study also found that one population sampled from a mild winter region was exclusively asexually reproduced and no pseudothecia could be found in this region.

The population from the Elgin region differed the most from the rest of the South African populations, as shown by the pairwise $\Phi_{\mathrm{PT}}$ values. This may be due to the Elgin region being a warmer winter apple growing region compared with the Koue Bokkeveld and Langkloof populations (Midgley and Lötze 2011). The Elgin region has also historically been the first place of apple cultivation in South Africa. This population therefore had a longer period to adapt to local conditions. Whereas orchards in the other regions were only introduced recently, therefore multiple pathogen introductions could have contributed to varying population structures. The Koue Bokkeveld and the two Langkloof populations showed little differentiation even though they are more than $600 \mathrm{~km}$ apart. The transportation of trees from nurseries may move inoculum from the one area to another. von Diest (2014) also found population differences between the Koue Bokkeveld and the Elgin regions, due to ascospore dispersal patterns and also the availability of pygmy apples with viable conidiospores early in the apple growing season in the warmer winter region of Elgin. There were no differences between populations from different orchards in the same region. The variance found in the PCA between the regions was comparable to what was found in Europe, i.e., $23 \%$ compared with $22 \%$ reported by Gladieux et al. (2010a).

The populations in this study shared a high percentage of identical alleles, indicating considerable gene flow among all of the South African $V$. inaequalis populations. This was also observed in the magnitude of migration between the regions. The Lower Langkloof area seems to have the highest migration rate toward it and the lowest away from it. This indicates that this region might be the most recently introduced apple scab population of the four or it might also be due to the absence of apple nurseries in that area. The Koue Bokkeveld region, where most of the apple plant nurseries are located, showed the highest incidence of migration events. Migration toward the Elgin region was the lowest, indicating that this region is isolated, probably due to climatic conditions of warmer winter temperatures. Overall, the migration results indicated the possible free movement of the pathogen between the regions.

In summary, the genetic variation and population structure in V. inaequalis in different apple growing regions in South Africa was investigated for the first time. High genetic variation was found within these populations, as was seen in the other $V$. inaequalis population studies conducted in Europe. Results indicated that gene flow between regions is definitely occurring and has significant implications for the apple industry if fungicide resistant isolates or resistance breaking $V$. inaequalis strains move between regions. The movement of infected planting material should be avoided. Furthermore, conidiospore sources should be controlled. Breeding programs need to make use of isolates from different apple growing regions when testing for scab resistance as there are differences between the populations.

\section{LITERATURE CITED}

Beck, A., Ritchel, A., Schubert, K., Braun, U., and Triebel, D. 2005. Phylogenetic relationship of the anamorphic genus Fusicladium s. lat. as inferred by ITS nrDNA data. Mycol. Prog. 4:111-116.

Beerli, P., and Felsenstein, J. 1999. Maximum-likelihood estimation of migration rates and effective population numbers in two populations using coalescent approach. Genetics 152:763-773.

Böhm, E. W. A., Freeman, S., Shabi, E., and Michailides, T. J. 2003. Microsatellite primers indicate the presence of asexual populations of Venturia inaequalis in coastal Israeli apple orchards. Phytoparasitica 31: 236-251.

Bowen, J. K., Mesarich, C. H., Bus, V. G. M., Beresford, R. M., Plummer, K. M., and Templeton, M. D. 2011. Venturia inaequalis: The causal agent of apple scab. Mol. Plant Pathol. 12:105-122.

Celton, J., Christoffels, A., Sargent, D. J., Xu, X., and Rees, J. G. 2010. Genome-wide SNP identification by high-throughput sequencing and selective mapping allows sequence assembly positioning using a framework genetic linkage map. BMC Biol. 8:155.

Crous, P. W., Schubert, K., Braun, U., De Hoog, G. S., Hocking, A. D., Shin, H., and Groenewald, J. Z. 2007. Opportunistic, human-pathogenic species in the Herpotrichiellaceae are phenotypically similar to saprobic or phytopathogenic species in the Venturiaceae. Stud. Mycol. 58:185-217.

Evanno, G., Regnaut, S., and Goudet, J. 2005. Detecting the number of clusters of individuals using software STRUCTURE: A simulation study. Mol. Ecol. 14:2611-2620.

Gessler, C., Patocchi, A., Sansavini, S., Tartarini, S., and Gianfranceschi, L. 2006. Venturia inaequalis resistance in apple. Crit. Rev. Plant Sci. 25:473-503.

Gladieux, P., Caffier, V., Devaux, M., and Le Cam, B. 2010a. Host-specific differentiation among populations of Venturia inaequalis causing scab on apple, pyracantha and loquat. Fungal Genet. Biol. 47:511-521.

Gladieux, P., Zang, X., Afoufa-Bastien, D., Sanhueza, R. V., Sbaghi, M., and Le Cam, B. 2008. On the Origin and spread of the scab disease of apple: Out of central Asia. PLoS One 3:e1455.

Gladieux, P., Zhang, X.-G., Róldan-Ruiz, I., Caffier, V., Leroy, T., Devaux, M., van Glabeke, S., Coart, E., and Le Cam, B. 2010b. Evolution of the population structure of Venturia inaequalis, the apple scab fungus, associated with the domestication of its host. Mol. Ecol. 19:658-674.

Guérin, F., Franck, P., Loiseau, A., Devaux, M., and Le Cam, B. 2004. Isolation of 21 new polymorphic microsatellite loci in the phytopathogenic fungus Venturia inaequalis. Mol. Ecol. Notes 4:268-270.

Holb, I. J. 2007. Classification of apple cultivar reactions to scab in integrated and organic production systems. Can. J. Plant Pathol. 29:251-260.

Jombart, T. 2008. Adegenet: An R package for the multivariate analysis of genetic markers. Bioinformatics 24:1403-1405.

Katoh, K., and Toh, H. 2008. Recent developments in the MAFFT sequence alignment program. Bioinformatics 9:286-298.

Kearse, M., Moir, R., Wilson, A., Stones-Havas, S., Cheung, M., Sturrock, S., Buxton, S., Cooper, A., Markowitz, S., Duran, C., Thierer, T., Ashton, B., Mentjies, P., and Drummond, A. 2012. Geneious Basic: An integrated and extendable desktop software platform for the organization and analysis of sequence data. Bioinformatics 28:1647-1649.

Le Cam, B., Devaux, M., and Parisi, L. 2001. Specific polymerase chain reaction identification of Venturia nashicola using internally transcribed spacer region in the ribosomal DNA. Phytopathology 91:900-904.

Le Cam, B., Parisi, L., and Arene, L. 2002. Evidence of two formae speciales in Venturia inaequalis, responsible for apple and Pyracantha scab. Phytopathology 92:314-320.

Louw, A. J. 1951. Studies on the influence of environmental factors on the overwintering and epiphytology of apple scab [Venturia inaequalis (Cke.) Wint.] in the winter-rainfall area of the Cape Province. Sci. Bull. Dep. Agric. S. Afr. 310:1-48.

MacHardy, W. E. 1996. Apple Scab: Biology, Epidemiology and Management. The American Phytopathological Society, St. Paul, MN.

MacOwan, P. 1889. Assay on "apple scab", "leaf blight", "leaf mildew" (Fusicladium dendriticum, Fckl.), a disease of the leaves and fruit of apple and pear trees. Agric. J. Cape Good Hope 7:181-182.

Matheny, P. B., Liu, Y. J., Ammirati, J. F., and Hall, B. D. 2002. Using RPB1 sequences to improve phylogenetic inference among mushrooms (Inocybe, Agaricales). Am. J. Bot. 89:688-698. 
Meitz-Hopkins, J. C., von Diest, S. G., Koopman, T. A., Bahramisharif, A., and Lennox, C. L. 2014. A method to monitor airborne Venturia inaequalis ascospores using volumetric spore traps and quantitative PCR. Eur. J. Plant Pathol. 140:527-541.

Midgley, S. J. E., and Lötze, E. 2011. Climate change in the Western Cape of South Africa: Trends, projections and implications for chill unit accumulation. Acta Hortic. 903:1127-1134.

Nei, M. 1973. Analysis of gene diversity in subdivided populations. Proc. Natl. Acad. Sci. 70:3321-3323.

Peakall, R., and Smouse, P. E., 2006. GENALEX 6: Genetic analysis in Excel. Population genetic software for teaching and research. Mol. Ecol. Notes 6: 288-295.

Pritchard, J. K., Stephens, P., and Donnelly, P. 2000. Inference of population structure using multilocus genotype data. Genetics 155:945-959.

Rambaut, A. 2002. Sequence Alignment Editor Version 2.0. University of Oxford, Oxford.

Samerpitak, K., Van der Linde, E., Choi, H. J., Gerrits van den Ende, A. H. G., Machouart, M., Gueidan, C., and de Hoog, G. S. 2014. Taxonomy of Ochroconis, genus including opportunistic pathogens on humans and animals. Fungal Divers. 65:89-126.

Sanchez-Torres, P., Hinarejos, R., and Tuset, J. J. J. 2009. Characterization and pathogenicity of Fusicladium eriobotryae, the fungal pathogen responsible for Loquat scab. Plant Dis. 93:1151-1157.

Schnabel, G., Schnabel, E. L., and Jones, A. L. 1999. Characterization of ribosomal DNA from Venturia inaequalis and ITS phylogenetic relationship to rDNA from other tree-fruit Venturia species. Phytopathology 89:100-108.

Schoch, C. L., Crous, P. W., Groenewald, J. Z., Boehm, E. W. A., Burgess, T. I., de Gruyter, J., de Hoog, G. S., Dixon, L. J., Grube, M., Gueidan, C., Harada, Y., Hatakeyama, S., Hirayama, K., Hosoya, T., Huhndorf, S. M., Hyde, K. D., Jones, E. B. G., Kohlmeyer, J., Kruys, A., Li, Y. M., Lücking, R., Lumbsch, H. T., Maranová, L., Mbatchou, J. S., McVay, A. H., Miller, A. N., Mugambi, G. K., Muggia, L., Nelson, P., Owensby, C. A., Phillips, A. J. L., Phongpaichit, S., Ponting, S. B., Pujade-Renaud, V., Raja, H. A., Rivas Plata, E., Robbertse, B., Ruibal, C., Sakayaroj, J., Sano, T., Selbmann, L., Shearer, C. A., Shirouzu, T., Slippers, B., Suetrong, S., Tanaka, K.,
Volkmann-Kohlmeyer, B., Wingfield, M. J., Wood, A. R., Woudenberg, J. H. C., Yonezawa, H., Zang, Y., and Spatafora, J. W. 2009. A class-wide phylogenetic assessment of Dothideomycetes. Stud. Mycol. 64:1-15.

Schuelke, M. 2000. An economic method for the fluorescent labelling of PCR fragments. Nat. Biotechnol. 18:233-234.

Stehmann, C., Pennycook, P., and Plummer, K. M. 2001. Molecular identification of a sexual interloper: The pear pathogen, Venturia pirina, has sex on apple. Phytopathology 91:633-641.

Tenzer, I., and Gessler, C. 1997. Subdivision and genetic structure of four populations of Venturia inaequalis in Switzerland. Eur. J. Plant Pathol. 103: 565-571.

Tenzer, I., and Gessler, C. 1999. Genetic diversity of Venturia inaequalis across Europe. Eur. J. Plant Pathol. 105:545-552.

Tenzer, I., Ivanissevich, S., Morgante, M., and Gessler, C. 1999. Identification of microsatellite markers and their application to population genetics of Venturia inaequalis. Phytopathology 89:748-753.

von Diest, S. G. 2014. Responses of Venturia inaequalis to sanitation and regional climate differences in South Africa. Ph.D. Thesis, Stellenbosch University, South Africa.

von Diest, S. G., Meitz-Hopkins, J. C., MacHardy, W. E., and Lennox, C. 2016. The effect of leaf shredding on apple scab in South African orchards. Plant Dis. 10:2094-2098.

Weir, B. S. 1997. Genetic Data Analysis II. Sinauer Associates Inc., Sunderland, MA.

White, T. J., Bruns, T., Lee, S., and Taylor, J. W. 1990. Amplification and direct sequencing of fungal ribosomal RNA genes for phylogenetics. Pages 315-322 in: PCR Protocols: A Guide to Methods and Applications. M. A. Innis, D. H. Gelfand, J. J. Sninsky, and T. J. White, eds. Academic Press, New York.

$\mathrm{Xu}, \mathrm{X}$., Harvey, N., Roberts, A., and Barbara, D. 2013. Population variation of apple scab (Venturia inaequalis) within mixed orchards in the UK. Eur. J. Plant Pathol. 135:97-104.

Xu, X., Yang, J., Thakur, V., Roberts, A., and Barbara, D. J. 2008. Population variation of apple scab (Venturia inaequalis) isolates from Asia and Europe. Plant Dis. 92:247-252. 